\title{
Kegiatan Pabrikasi Mesin Pengupas Bawang Merah Merek BEJE Tipe PB 01 di PT Bahagia Jaya Sejahtera
}

\section{The Production of Shallot Dehulling Machine BEJE PB 01 at PT Bahagia Jaya Sejahtera}

\author{
Widiya Apriliani ${ }^{1 *}$, Linda Liswanti ${ }^{1}$, Titis Pury Purboningtyas ${ }^{2}$ \\ ${ }^{1}$ Program Studi Teknologi Mekanisasi Pertanian \\ ${ }^{2}$ Program Studi Penyuluhan Pertanian Berkelanjutan \\ Jurusan Pertanian, Politeknik Pembangunan Pertanian Bogor \\ Korespondensi penulis, E-mail: widiyazm@gmail.com
}

\begin{abstract}
Shallot peeling in small scale industries are usually done manually. This process requires a lot of time and effort. To obtain time efficiency, the dehulling machine with low electric power and easy to use is needed. This study aimed to produce a shallot dehulling machine at PT Bahagia Jaya Sejahtera using the concept of machine design and manufacture. The tools used were workshop tools and the materials were stainless plats and angle iron. The production process started after the design is finished and approved. This process included the making of dehulling chamber, inlet, outlet, and machine frame. Then, those parts were assembled and properly furnished. The product then was tested its functional design to observe its working ability. Functional tests were conducted without and with shallots. The test without shallots showed that each component worked well. The test with shallots showed that the modification was needed for some parts to improve its functions.
\end{abstract}

Keywords: functional test, manufacturing, shallot

\begin{abstract}
ABSTRAK
Pengupasan bawang merah pada usaha industri kecil masih dilakukan secara manual sehingga memerlukan banyak waktu dan tenaga. Oleh karena itu, diperlukan mesin pengupas bawang merah yang kebutuhan listriknya rendah dan mudah digunakan. Penelitian ini bertujuan untuk melakukan kegiatan pabrikasi mesin pengupas bawang di PT Bahagia Jaya Sejahtera dengan menggunakan konsep desain dan pabrikasi mesin. Alat yang digunakan merupakan peralatan perbengkelan yang menunjang pembuatan mesin pengupas bawang. Adapun bahan yang digunakan adalah pelat baja tahan karat dan besi siku. Proses produksi berlangsung setelah proses desain selesai dan rancangan mesin telah disetujui. Proses produksi meliputi kegiatan pembuatan rumah pencacah, unit pengumpan (inlet), unit pengeluaran (outlet), dan rangka mesin. Setelah itu, semua bagian mesin disusun dan dilakukan kegiatan finishing. Sebelum mesin tersebut didistribusikan, dilakukan uji fungsional alat untuk mengetahui performa mesin tersebut. Hasil uji fungsional dilakukan tanpa beban dan dengan beban. Hasil uji tanpa beban menunjukkan bahwa setiap bagian mesin bekerja dengan baik. Hasil uji fungsional dengan beban menunjukkan bahwa perlu beberapa perbaikan komponen untuk meningkatkan kemampuan mesin pengupas bawang.
\end{abstract}

Kata kunci: bawang merah, pabrikasi, uji fungsional 


\section{PENDAHULUAN}

Bawang merah merupakan herba tahunan dari famili Liliaceae yang banyak tumbuh hampir di seluruh penjuru dunia. Bawang merah termasuk dalam genus Allium yang umbinya sering digunakan sebagai penyedap rasa makanan atau bumbu serta mempunyai berbagai macam khasiat obat (Dharmawibawa et al, 2014). Bawang merah merupakan salah satu tanaman yang luas dibudidayakan di Indonesia. Tanaman ini identik dengan baunya yang tajam dan mengandung zat yang dapat membuat mata perih. Bawang merah merupakan tanaman hortikultura yang punya peranan tinggi selain bawang putih, cabai merah besar, cabai rawit, kentang, tomat, dan wortel (BPS 2020). Kebutuhan bawang merah tiap tahunnya selalu mengalami peningkatan sesuai dengan tingginya permintaan pasar. Permintaan bawang merah cenderung merata setiap saat sementara produksi bawang merah bersifat musiman (Sugiyanto 2015).

Badan Pusat Statistik

Kabupaten Bogor (2020) menyatakan bahwa produksi bawang merah di Kabupaten Bogor pada tahun 2020 yaitu sebesar 33.000 kuintal dengan kenaikan angka kebutuhan bawang merah perbulan sebesar $8,44 \%$. Konsumsi bawang merah ini Sebagian besar berasal dari rumah tangga (BPS 2020). Meskipun demikian, kenaikan permintaan dari usaha kecil menengah juga meningkat dan ini juga meningkatkan permintaan bawang merah yang sudah dikupas. Ketika permintaan hariannya tinggi namun produktivitasnya rendah maka ketersediaan bawang merah di pasar fluktuatif dan menyebabkan adanya fluktuasi harga (Dahar 2017).

Pengupasan bawang bertujuan menghilangkan kulit bagian luar bawang (Sahruddin et al. 2018). Pengupasan secara konvensional dilakukan dengan menggunakan pisau. Meskipun hasil pengupasan baik, tetapi cara ini membutuhkan waktu dan tenaga yang besar. Oleh karena itu, mesin pengupas bawang dirancang. Tujuannya adalah untuk mendapatkan proses pengupasan yang lebih cepat dan lebih banyak sehingga meningkatkan efisiensi pengupasan. Cara kerja mesin pengupas bawang pada umumnya adalah memutar ruang pengupas bawang yang memiliki gigi pengupas di bagian dindingnya. Kontak yang terjadi antara bawang dengan gigi pengupas inilah yang menyebabkan kulit bawang terpisah (Wijaya dan Rodiah 2020).

Menurut pendapat Heizer dan Render (2014), proses produksi pada dasarnya adalah suatu kegiatan yang mengubah input menjadi output atau 


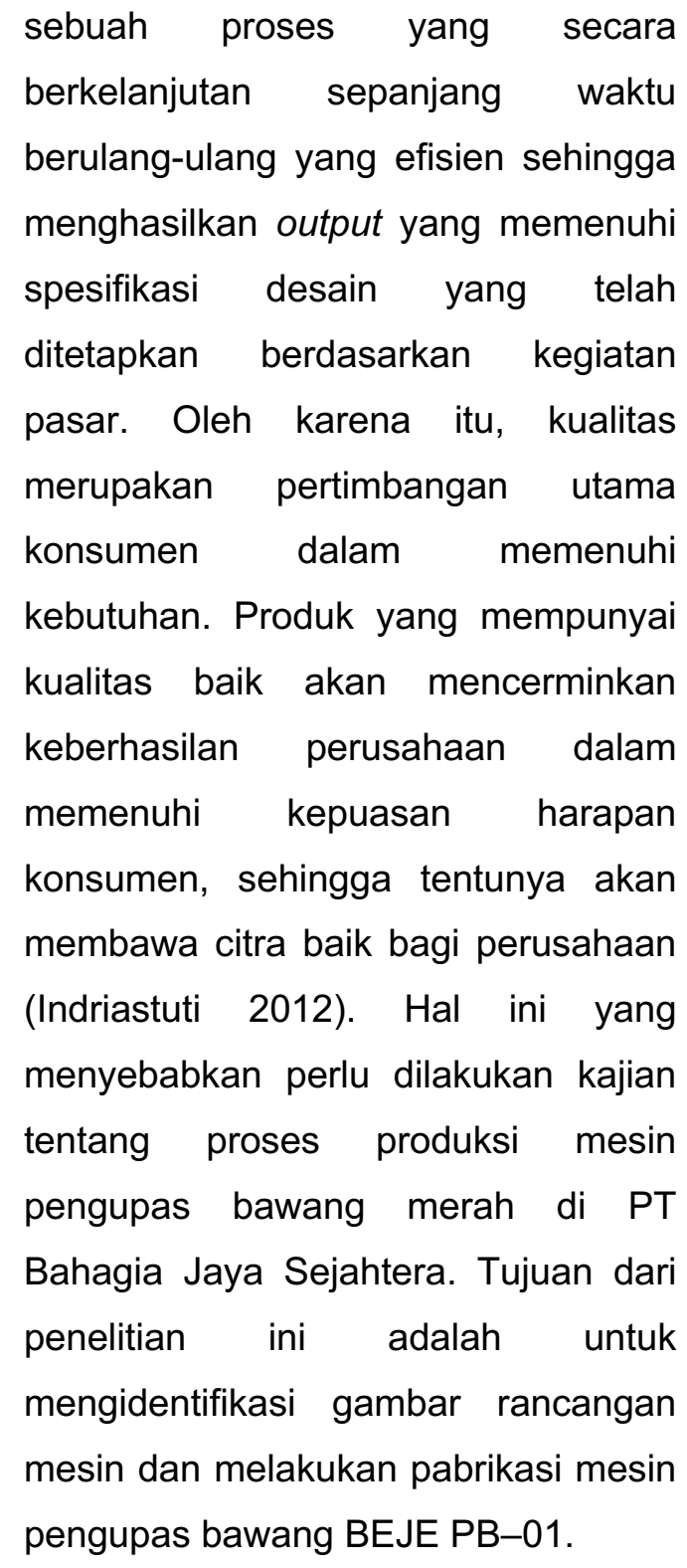

\section{METODE}

Penelitian ini dilakukan pada bulan Mei hingga Juli 2021. Tempat pelaksanaan dilakukan di PT Bahagia Jaya Sejahtera yang beralamat di Jalan Mayjen H.E. Sukma No. 58 Kecamatan Ciawi Kabupaten Bogor Jawa Barat. Jenis pengkajian dalam penelitian adalah analisis kualitatif deskriptif.
Pengkajian kualitatif penulis dapat terjun langsung untuk mengadakan wawancara dengan responden, observasi, bahkan penulis turut serta dalam proses untuk mengetahui secara mendalam (Rukajat 2018). Kegiatan yang dilakukan dengan melaksanakan kegiatan produksi dan pabrikasi mesin pengupas bawang merah sepertidesain struktural dan desain fungsional, membuat mesin pengupas bawang mulai dari tahapan desain gambar hingga menjadi produk akhir, dan melakukan kegiatan uji fungsional mesin pengupas bawang merah di PT Bahagia Jaya Sejahtera.

\section{Alat dan Bahan}

Peralatan yang digunakan adalah peralatan perbengkelan seperti mesin gerinda duduk, mesin gerinda tangan, meteran, penggaris siku, kapur besi, mesin bor duduk, mesin bor tangan, mata bor, penitik, mesin las beserta kelengkapannya, sikat besi, mesin roll, mesin penekuk, dan mesin cutting plasma. Adapun bahan yang digunakan antara lain besi pelat, roda, dan besi siku serta bahan pengujian fungsional yaitu bawang merah.

\section{Pengumpulan Data}

Pengumpulan data yang
digunakan dalam penelitian ini
mencakup beberapa parameter seperti
yang ditunjukkan dalam Tabel 1 berikut.


Tabel 1 Parameter analisis data

\begin{tabular}{|c|c|c|}
\hline Tujuan & Parameter & Kegiatan \\
\hline \multirow[b]{2}{*}{$\begin{array}{l}\text { Identifikasi } \\
\text { alat dan bahan }\end{array}$} & Rancangan mesin & Penentuan alat dan bahan \\
\hline & Alat dan bahan & $\begin{array}{l}\text { Kegiatan pembuatan mesin seperti } \\
\text { pengukuran, pengeboran, pemotongan, } \\
\text { pengelasan, perakitan, dan finishing. }\end{array}$ \\
\hline \multirow{2}{*}{$\begin{array}{l}\text { Melakukan } \\
\text { pabrikasi } \\
\text { mesin }\end{array}$} & Proses pembuatan mesin & $\begin{array}{l}\text { Proses pembuatan komponen-komponen } \\
\text { mesin pengupas bawang }\end{array}$ \\
\hline & Proses perakitan & Kegiatan perakitan komponen \\
\hline \multirow{3}{*}{$\begin{array}{l}\text { Analisis kinerja } \\
\text { mesin }\end{array}$} & Uji fungsional & Uji kinerja masing-masing komponen \\
\hline & Evaluasi & Menganalisis permasalahan yang muncul \\
\hline & Modifikasi & $\begin{array}{l}\text { Memberi saran perbaikan untuk } \\
\text { meningkatkan performa mesin }\end{array}$ \\
\hline
\end{tabular}

HASIL DAN PEMBAHASAN

Identifikasi Alat dan Bahan

Rancangan Mesin

Proses perancangan mesin pengupas bawang merah menggunakan software Solidworks.
Bagian-bagian mesin yang dirancang antara lain unit pengumpan bahan (inlet), ruang pengupas, unit pengeluaran bahan (outlet), rangka mesin, dan dudukan motor penggerak. Rancangan mesin dapat dilihat pada Gambar 1 berikut.

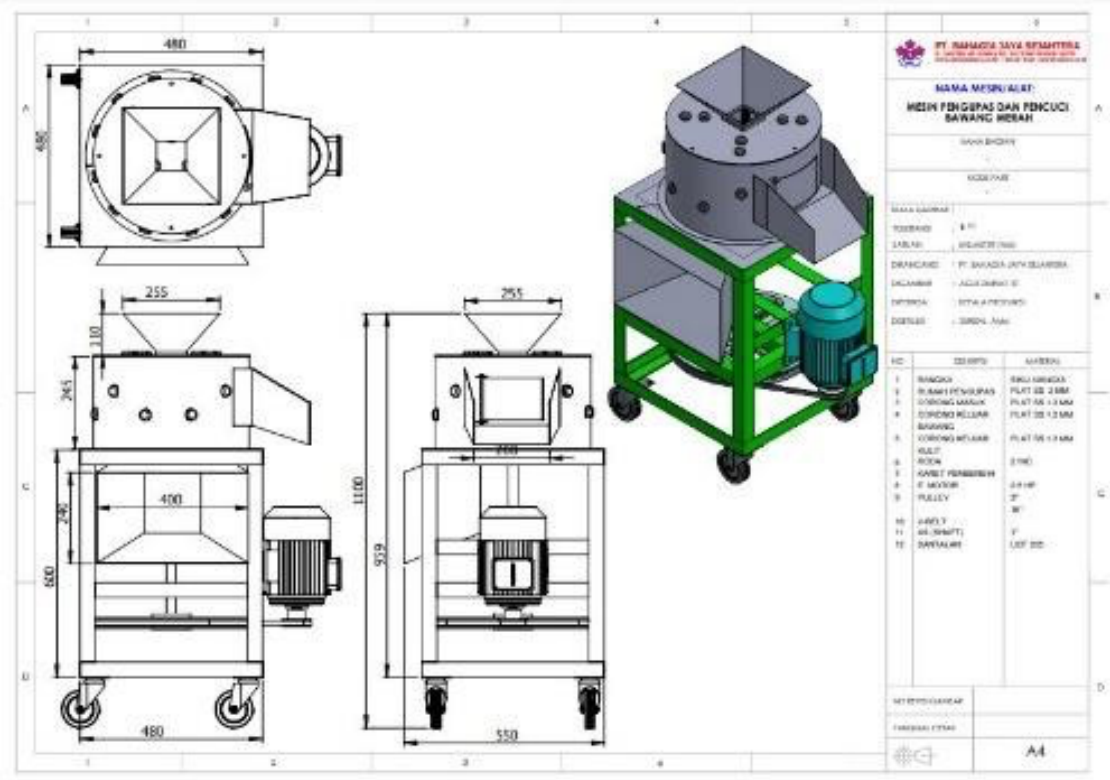

Gambar 1 Rancangan mesin

Proses perancangan mesin selain meliputi desain gambar teknik mesin, diperlukan pula ukuran dan jenis 
material yang digunakan (bill of material). Hal ini dilakukan agar material yang digunakan sesuai dengan spesifikasi. Pemilihan bahan yang tepat akan mendukung ketahanan mesin dalam bekerja. Muhammad et al. (2021) yang melakukan penelitian di PT
Bahagia Jaya Sejahtera dan melakukan pabrikasi mesin giling kopi kering juga melakukan pabrikasi setelah proses desain dan bill of material selesai dirancang. Adapun material yang dipilih beserta dimensinya disajikan pada Tabel 2 berikut.

Tabel 2 Spesifikasi mesin

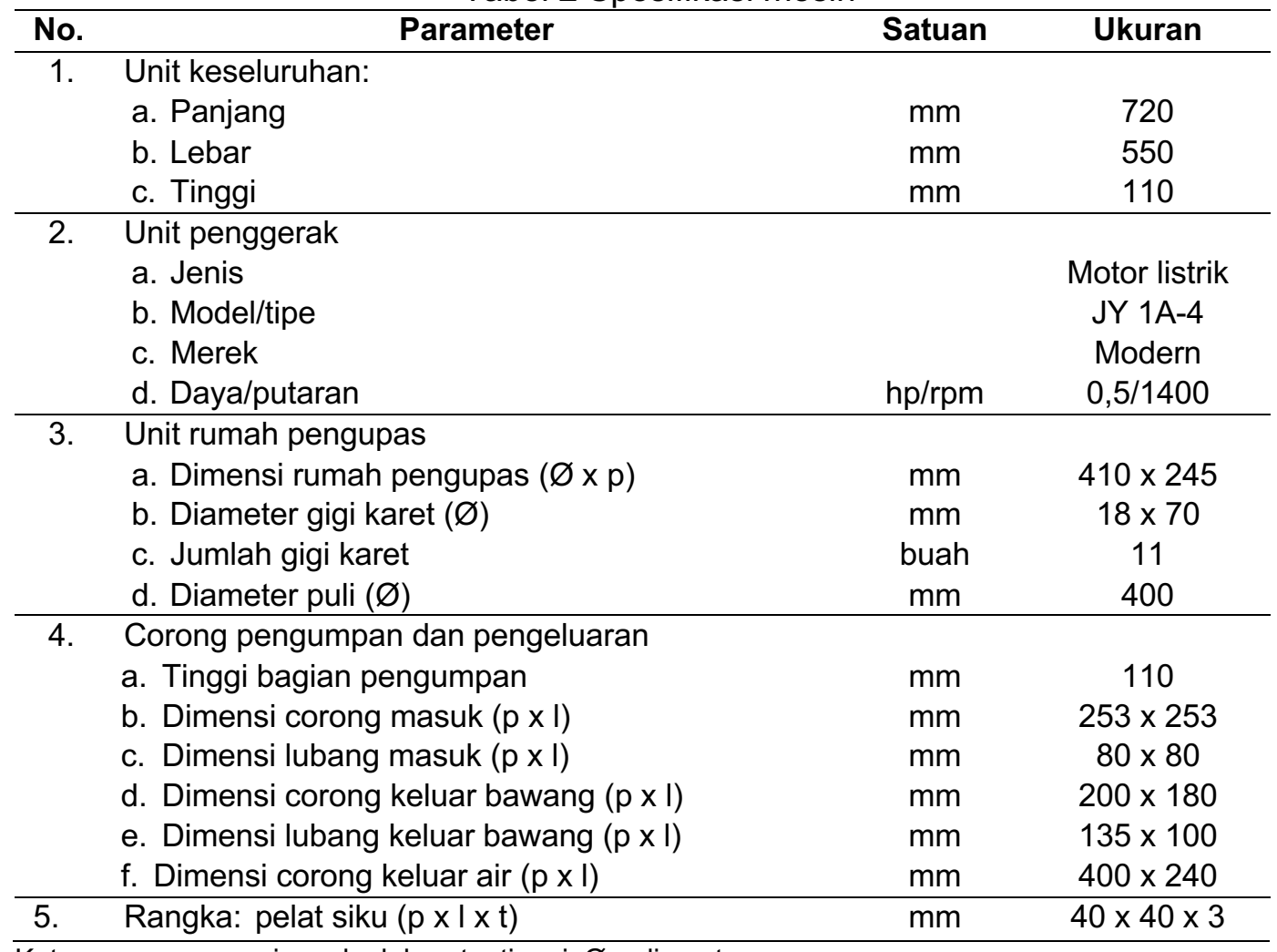

Keterangan: $\mathrm{p}=$ panjang, $\mathrm{I}=$ lebar, $\mathrm{t}=$ tinggi, $\varnothing=$ diameter

\section{Pembuatan Mesin}

\section{Proses Pembuatan Komponen}

Proses pembuatan komponen mesin pengupas bawang merah dilakukan dengan mengikuti hasil rancangan mesin dengan menggunakan alat dan bahan yang sesuai. Proses pembuatan mesin pengupas bawang meliputi tahapan- tahapan sebagai berikut.

1. Proses pembuatan rangka mesin Proses pembuatan rangka mesin pengupas bawang diawali dengan pemotongan besi siku ukuran $40 \mathrm{x}$ $40 \times 4 \mathrm{~mm}$ dengan ukuran $480 \mathrm{~mm}$ sebanyak 17 buah dan ukuran 520 $\mathrm{mm}$ sebanyak 4 buah, dan roda sebanyak 4 buah berukuran 1 inci. Setelah proses pemotongan selesai, 
dilanjutkan proses pemasangan roda pada rangka mesin dan dilanjutkan dengan pengelasan menggunakan las listrik $\mathrm{CO}_{2}$. Kegiatan pemolesan di bagian akhir menggunakan gerinda tangan poles.

2. Proses pembuatan rumah pengupas Rumah pengupas bawang ini berfungsi sebagai tempat penampung bawang yang belum dan sudah terkupas ketika mesin berjalan. Proses pembuatan rumah pengupas diawali dengan pemotongan pelat stainless steel berdiameter $225 \mathrm{~mm}$ dengan

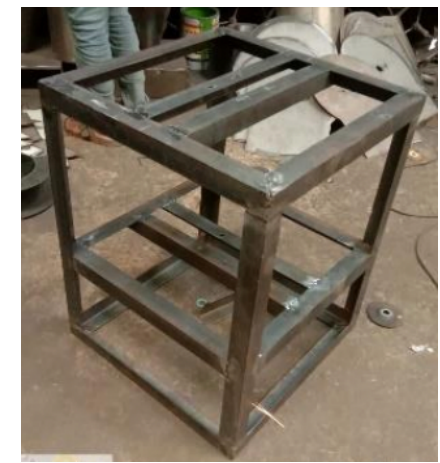

(a) ketebalan 1,2 $\mathrm{mm}$ menggunakan mesin cutting plasma. Selanjutnya, pemolesan bagian yang masih kasar menggunakan gerinda tangan poles, setelah itu dilakukan pemolesan kembali menggunakan nilon bertujuan untuk menghaluskan dan mengilapkan permukaan stainless steel. Selanjutnya, melakukan proses rolling menggunakan mesin roll. Kemudian dilanjutkan dengan penggabungan bagian menggunakan las argon. Gambar 2 menunjukkan hasil pembuatan rangka mesin dan rumah pengupas.

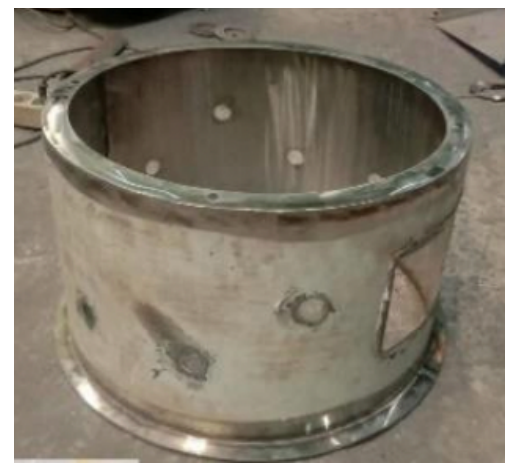

(b)

Gambar 2 Pembuatan komponen, a) rangka mesin dan b) rumah pengupas

3. Proses pembuatan ruang pemasukan

Proses pembuatan ruang pemasukan (inlet) diawali dengan pemotongan pelat stainless steel berdiameter $410 \mathrm{~mm}$ dengan ketebalan 1,2 $\mathrm{mm}$ menggunakan mesin cutting plasma. Kegiatan kemudian dilanjutkan dengan pemolesan bagian yang masih kasar menggunakan gerinda tangan poles dan nilon. Pelat yang sudah dipoles dilanjutkan dengan penekukan. Kemudian dilanjutkan dengan penggabungan bagian menggunakan las argon dan dipoles. Proses pembuatan piringan pembuang kulit

Proses pembuatan piringan pembuang kulit diawali dengan pemotongan pelat stainless steel berdiameter $395 \mathrm{~mm}$ dengan 
ketebalan $3 \mathrm{~mm}$ menggunakan mesin cutting plasma, pemotongan as stainless steel dan pipa yang berukuran $50 \mathrm{~mm}$ dengan ketebalan 1 inci. Setelah itu dilanjutkan dengan pemolesan bagian yang masih kasar menggunakan gerinda tangan poles dan nilon. Kegiatan selanjutnya

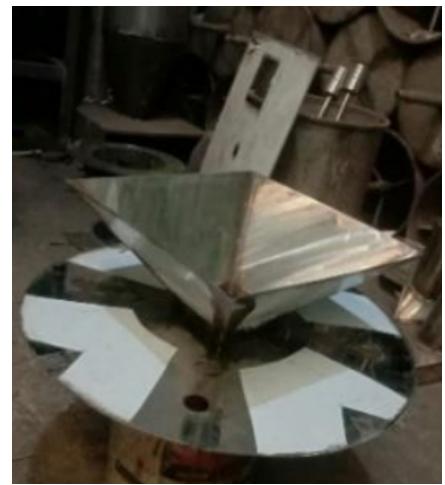

(a)

Gambar 3 Komponen mesin pengupas bawang, a) inlet dan b) piringan pembuang kulit

4. Proses pembuatan ruang pembuangan kulit

Bagian ini berfungsi sebagai tempat keluarnya kulit bawang yang sudah terkelupas. Proses pembuatan outlet kulit bawang diawali dengan pemotongan pelat stainless steel berukuran $400 \mathrm{~mm}$ dengan ketebalan 1,2 $\mathrm{mm}$ menggunakan mesin cutting plasma. Selanjutnya dilakukan pemolesan bagian yang masih kasar menggunakan gerinda tangan poles dan nilon. Pelat kemudian ditekuk lalu bagianbagian tersebut digabung menggunakan las argon.

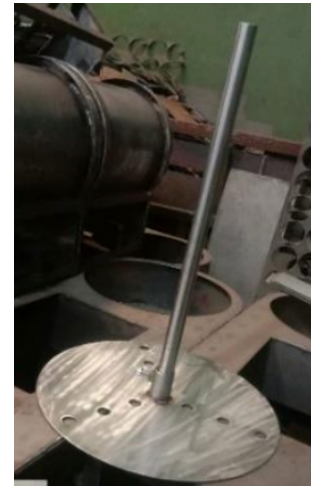

(b) adalah pengeboran untuk melubangi bagian yang akan disambungkan ke puli dan bantalan menggunakan baut dan mur dan disambung menggunakan las argon. Gambar 3 menunjukkan hasil pabrikasi ruang pemasukan dan pembuang kulit.

5. Proses pembuatan ruang keluar bawang (outlet)

Bagian ini berfungsi sebagai tempat keluarnya bawang yang sudah terkelupas. Proses pembuatan outlet bawang diawali dengan pemotongan pelat stainless steel berukuran 250 $\mathrm{mm}$ dengan ketebalan $1,2 \mathrm{~mm}$ menggunakan mesin cutting plasma. Selanjutnya dilakukan pemolesan bagian yang masih kasar menggunakan gerinda tangan poles dan dilanjutkan dengan nilon. Pelat setelah itu ditekuk dan digabung menggunakan las argon. Gambar 4 menunjukkan hasil pabrikasi ruang 


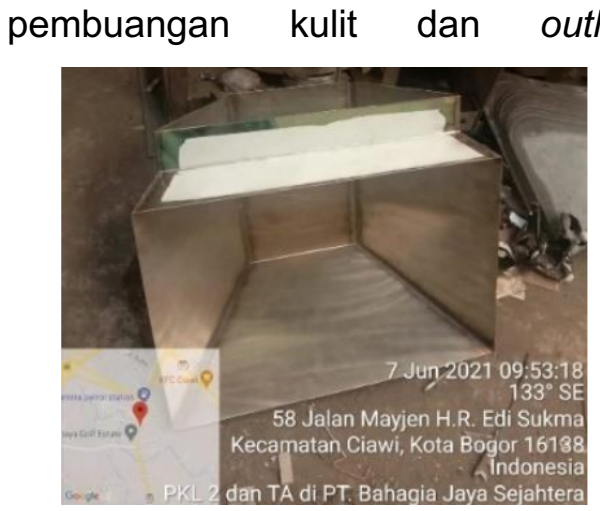

(a) bawang.

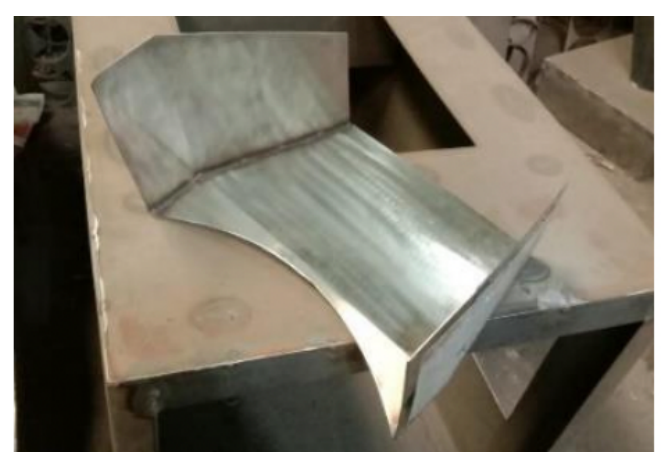

(b)

Gambar 4 Komponen pengeluaran, a) kulit bawang dan b) bawang utuh

\section{Proses Perakitan Mesin}

Setelah semua komponen selesai dibuat dan dipoles, tahap selanjutnya adalah perakitan. Tahap ini menggabungkan bagian-bagian mesin yang terdiri atas rangka, rumah pengupas, inlet pengupas, piringan pembuang kulit, outlet kulit bawang, dan outlet bawang, motor penggerak, bantalan, as, puli dan karet pengupas. Mesin pengupas bawang merah hasil penggabungan dapat dilihat pada Gambar 5 berikut.

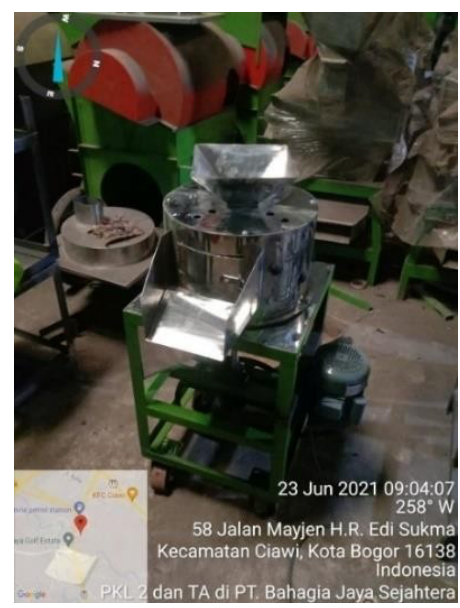

Gambar 5 Mesin pengupas bawang merah

\section{Analisis Kinerja Mesin Uji Fungsional}

Uji fungsional dilakukan dengan melakukan pengujian kerja pada saat motor penggerak dioperasikan saat tidak ada beban (bawang merah) dan saat ada beban selama lima menit.
Selanjutnya dilakukan pengamatan kinerja bagian-bagian mesin tersebut. Massa bawang yang digunakan saat uji fungsional sebanyak $2 \mathrm{~kg}$ dengan tiga kali ulangan.

Pengoperasian tanpa beban dilakukan dengan menghidupkan motor penggerak. Hasil uji yang diperoleh 
hasil antara lain:

1. Rangka pada mesin pengupas berhasil dipabrikasi dengan baik karena tidak bergetar saat motor menyala.

2. Sambungan antar komponen telah baik dibuktikan tidak adanya kerusakan selama pengoperasian

3. Mesin pengupas bekerja (berputar) dengan baik.

Hasil uji fungsional dengan beban bawang merah sebanyak $2 \mathrm{~kg}$ tiap ulangan diperoleh hasil sebagai berikut:

1. Terjadi loncatan bawang merah melalui inlet di bagian atas. Hal ini terjadi karena bagian inlet tidak memiliki penutup sehingga bawang yang bergesekan selama pengoperasian dapat keluar dari ruang pengupasan.

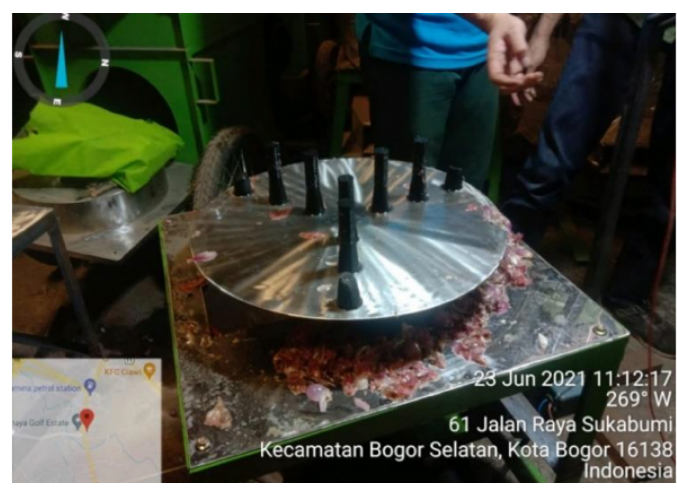

(a)
2. Terdapat bawang yang rusak/pecah. Hal ini disebabkan adanya celah pada piringan pembuang kulit yang cukup renggang sehingga pada proses pengupasan, bawang yang berukuran kecil akan pecah dan masuk ke ruang tersebut.

3. Residu hasil pengupasan menumpuk di bagian bawah piringan. Sehingga harus dilakukan pembersihan residu secara manual. Selain itu, kulit hasil pengupasan tidak tertampung dengan baik karena belum adanya wadah penampung. Akibatnya, kulit hasil kupasan bertebaran di lantai. Gambar 6 menunjukkan hasil pengujian kinerja saat ada beban bawang merah.

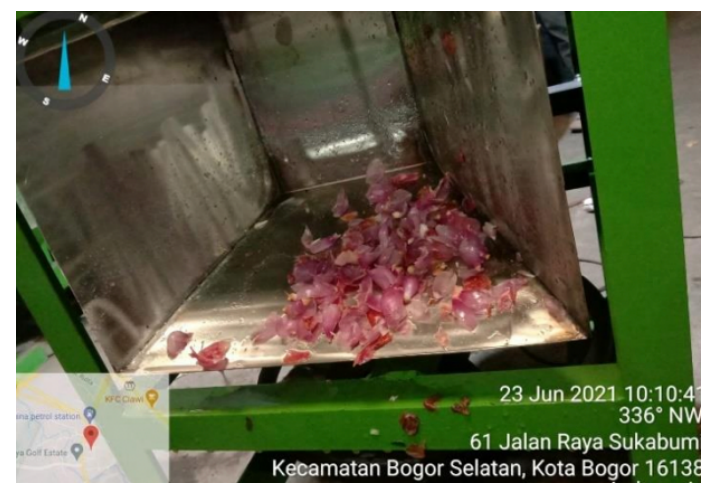

(b)

Gambar 6 Hasil uji dengan beban, a) celah yang renggang dan b) sisa kupasan

4. Bagian motor penggerak tidak memiliki penutup dan penyalaan motor penggerak langsung dihubungkan langsung lewat stop kontak. Bagian motor penggerak yang tidak terlindungi cukup berbahaya bagi operator selama pengoperasian mesin. Motor penggerak disambung dengan penerus gaya yaitu puli dan sabuk- $V$ dan merupakan bagian yang berputar selama pengoperasian. 
Gambar 7 menunjukkan kondisi motor penggerak yang terbuka.

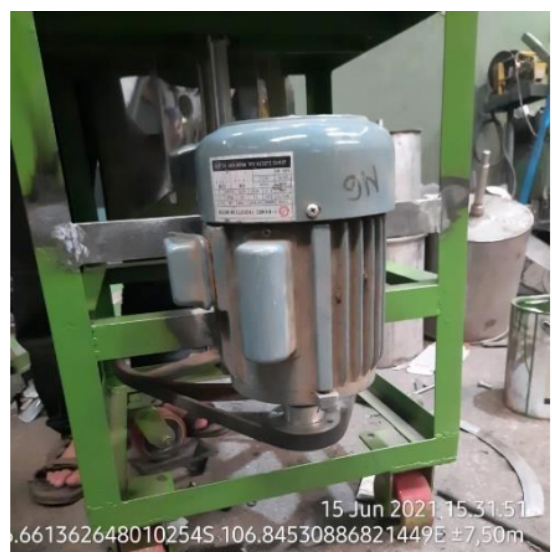

Gambar 7 Motor penggerak

\section{Perbaikan Mesin Pengupas Bawang Merah}

Berdasarkan hasil uji fungsional yang dilakukan maka perlu adanya perbaikan pada mesin pengupas bawang merah antara lain:

1. Penambahan penampung kulit hasil pengupasan

Penambahan penampung pada mesin ini bertujuan agar bawang merah yang keluar dari corong memiliki wadah penampungan dan pada saat pembersihan mesin setelah digunakan residu yang

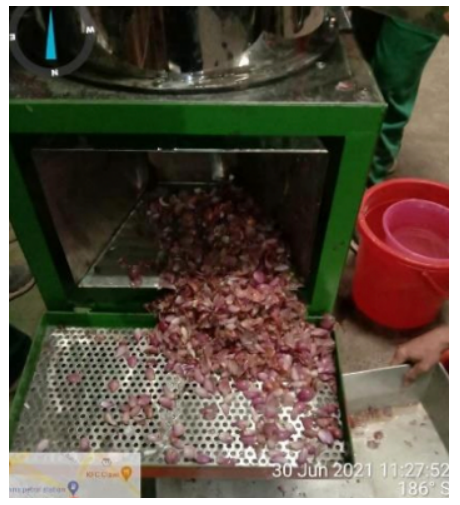

(a) tertinggal dapat tertampung dengan baik.

2. Penambahan dinding rangka mesin Penambahan dinding rangka mesin ini berfungsi untuk melindungi operator dan menutupi celah yang terhubung dengan sistem transmisi seperti puli, sabuk-v, dan motor penggerak. Penambahan ini mencegah benda yang tidak diinginkan masuk ke dalam rangka dan tidak mengganggu sistem transmisi. Hasil modifikasi penampung dan dinding rangka dapat dilihat pada Gambar 8 berikut.

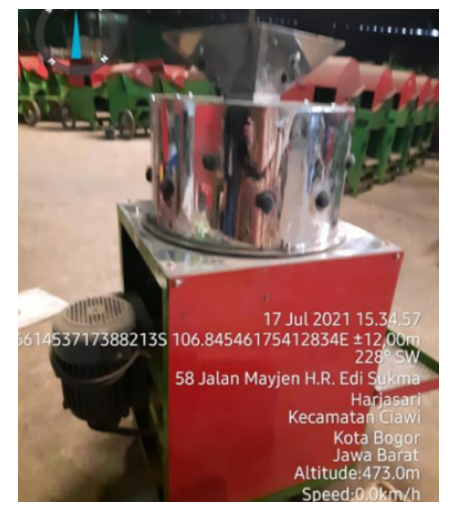

(b) 
Gambar 8 Hasil modifikasi mesin, a) penampung dan b) penambahan dinding rangka

3. Penambahan sakelar mesin lebih mudah dilakukan. Motor penggerak sebelumnya langsung dihubungkan ke stop Gambar 9 menunjukkan kontak. Oleh karena itu, modifikasi yang dilakukan adalah penambahan sakelar sehingga pengoperasian

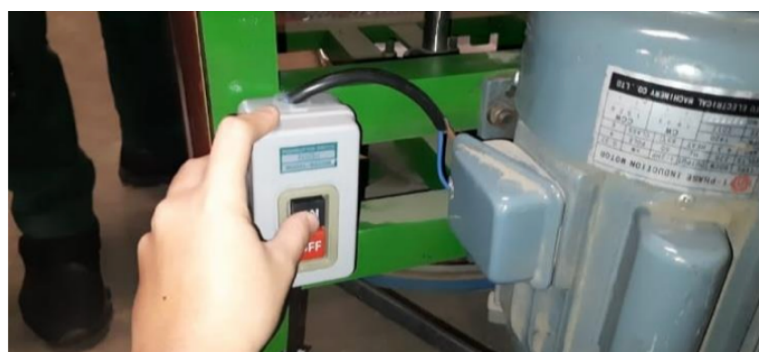

Gambar 9 Sakelar untuk pengoperasian motor

\section{SIMPULAN DAN SARAN}

\section{Simpulan}

1. Mesin pengupas bawang telah dipabrikasi lewat tahapantahapan antara lain pembuatan rangka mesin, rumah pengupas, piringan pembuang kulit, inlet pengupas, outlet kulit bawang dan outlet bawang. Setelah itu, tiap komponen dipoles dan dirakit dengan menggabungkan setiap komponen mesin hingga menjadi produk akhir.

2. Hasil uji fungsional tanpa beban menujukkan kerja mesin pengupas telah baik dan sesuai dengan fungsi yang dirancang. Hasil uji fungsional dengan beban menunjukkan hasil bahwa terdapat bawang yang keluar dari ruang pengupas dan rusak sehingga diperlukan perbaikan beberapa komponen.

3. Hasil perbaikan yang dilakukan antara lain berupa penambahan saringan, tutup inlet, dinding motor penggerak, dan sakelar

\section{Saran}

Perlu dilakukan uji kinerja performa untuk melihat efisiensi pengupasan kulit bawang dan persentase bawang merah yang rusak.

\section{DAFTAR PUSTAKA}

[BPS] Badan Pusat Statistik. 2020. Statistik Hortikultura. Jakarta: Badan Pusat Statistika

[BPS Kab. Bogor] Badan Pusat Statistik 
Kabupaten Bogor. 2020. Produksi

Tanaman Sayuran Menurut Kecamatan dan Jenis Tanaman. Bogor: Badan Pusat Statistik KabupatenBogor.

Dahar D. Analisis permintaan bawang merah. Jurnal Agropolitan. 4(1): 14-24.

Dharmawibawa ID, Hulyadi, Baiq LY, dan Santy P. 2014. Antibacterial effect of allium group for MRSA bacteria. Media Bina IImiah. 8(6):63-67.

Heizer J, Render B. 2014. Manajemen Operasi: Manajemen Keberlangsungan dan Rantai Pasokan. Jakarta: Salemba Empat.

Indriastuti M. 2012. Analisis kualitas auditor dan corporate governance terhadap manajemen laba. Jurnal Akutansi. 4(2): 532-542.

Muhammad RW, Purboningtyas TP, Widiono E, Tohari. 2021. Kegiatan Pabrikasi Mesin Giling Kopi Kering Merek BEJE Tipe GLK 20 di PT Bahagia Jaya Sejahtera. Jurnal Agroekoteknologi dan Agribisnis. 5(1): 36-46.

Rukajat A. 2018. Pendekatan Penelitian Kualitatif. Yogyakarta. Deepublish.

Sahruddin, Putra DR, Oktoricoento JS,
Mujirudin M, Ramza H. 2018. Mesin pengupas bawang mudahalih. National Seminar Teknoka Proceeding. 3: 43-49.

Sugiyanto. $2015 . \quad$ Strategi Pengembangan Tanaman Bawang Merah Berbasis Agribisnis di Desa Duwel Kecamatan Kedungadem Kabupaten Bojonegoro. Diunduh Oryza: Jurnal Agribisnis dan Pertanian Berkelanjutan. 1(1): 111

Wijaya W, Rodiah. 2020. Analisis dan perancangan mesin pengupas bawang skala industry perumahan (Studi kasus Koperasi Produksi Mitra Kelapa Sidahurip Kabupaten Pangandaran). Jurnal Universitas Kebangsaan. 3 (1): 28-33. 